\title{
Government Suits Against In-Service Conscientious Objectors Who Have Received Educational Benefits: An Examination of Justiciability and Damages
}

\begin{abstract}
A number of military programs offer college, graduate, or professional training in exchange for an individual's commitment to serve a specified tour of duty in the armed forces of the United States following graduation. ${ }^{1}$ The Government can normally deal with refusals to perform the agreement to serve by the sanctions of induction, prosecution under the Uniform Code of Military Justice, or, under limited circumstances, ${ }^{2}$ alternative civilian service. Re-
\end{abstract}

1 The following programs have been the focus of the cases discussed in this comment:

Government-sponsored medical education: The Secretary of the Air Force is authorized to detail personnel as students at civilian educational institutions by 10 U.S.C. $\S 9301$ (1970). 32 C.F.R. $\$ 888$ c.30 (1974) provides that where the Government sponsors education toward the M.D. under such an arrangement, the member will agree to serve three months as a medical officer for every month (or fraction thereof) of sponsored professional training. Smith v. Laird, 486 F.2d 307 (10th Cir. 1973).

Air Force Undergraduate and Advanced Pilot Training: additional minimum service requirements are imposed by 32 C.F.R. $\$ 888$ c.20 (1973) on Air Force Officers who elect to attend pilot training. Mosley v. Commanding Officer, 480 F.2d 1107 (8th Cir. 1973).

NESEP (Naval Enlisted Scientific Education Program): this program involves a contractual relationship between the Department of the Navy and the applicant, invoking no statutory authority beyond the funding provisions of the defense appropriation acts. The member signs a form by which he agrees to serve nine months of active duty as an officer for each six months of college education sponsored by the Navy. Miller v. Chafee, 462 F.2d 335 (9th Cir. 1972).

Air Force Academy: 10 U.S.C. $\$ 9348(a)(2)(1970)$ requires Academy cadets to sign an agreement to accept appointment to serve for at least five years following graduation. McCullough v. Seamans, 348 F. Supp. 511 (E.D. Cal. 1972).

There is evidence that the armed services hope to rely increasingly on these programs to secure volunteers who will place valuable skills at the disposal of the military. With the draft no longer available as an incentive to enlist, the Navy, for example remains "optimistic that we can [retain quality personnel], especially if we properly use the lure of education and training as an incentive for recruiting and retention." Statement of the Director of Naval Education and Training, United States Navy, Hearings on S. 1263 Before the Senate Comm. on Armed Services, 93d Cong., 1st Sess., pt. 8, at 5672 (1973).

In addition, the Department of Defense Tuition Assistance programs for undergraduate education alone are expected to show an increase from 32,630 participants in fiscal 1974 to 49,960 participants for fiscal 1975. Hearings on Military Posture and H.R. 12564 Before Subcomm. No. 2 (Military Personnel) of the House Comm. on Armed Services, 93d Cong., 2d Sess., pt. 3, at 2956 (1974).

2 Section VI(c)2 of Department of Defense (DoD) Directive 1300.6 states that: “[P]ersons with less than 180 days' service who are determined to be conscientious objectors 
fusal to serve the specified tour of duty on the basis of conscientious objection to military activity is uniquely troublesome because it places the nonperforming individual beyond the reach of the remaining effective remedies of induction and prosecution.

Conscientious objector status, at first available only to those inducted under the Selective Service System, was extended to individuals already on active duty by a Defense Department Directive in $1962 .{ }^{3}$ The services at first treated the exemption, which provides for the discharge of conscientious objectors with more than 180 days of active duty, as entirely within their discretion. By 1968, however, the federal courts ${ }^{4}$ had asserted a right of limited judicial review whereby the record of the military administrative proceedings may be examined and the applicant discharged from service by a writ of habeas corpus if no "basis in fact" is found for an adverse decision." These developments, combined with the Supreme Court's relaxation of the requirements for conscientious objector classification, ${ }^{6}$ have brought sharply into focus the question of the Government's recourse when in-service ${ }^{7}$ recipients of educational benefits are discharged as conscientious objectors while still owing terms of active

and whose request for separation is made early enough so that discharge will occur prior to completion of 180 days' active duty will be separated early enough to permit the remaining service in the civilian work program administered by Selective Service." The alternative service apparatus has not been available since November, 1974, when all those in the civilian work program were to be released and the program terminated. See Selective Service Temporary Instruction, 17 Oct. 1974, Subject: Early Release from Alternative Service. Although the program has ended, it may be reactivated in the future if the number of conscientious objectors becomes large enough to make the program economically efficient. The Department of Defense Directive has not been amended to take into account the temporary termination of the alternative service program.

${ }^{3}$ DoD Directive 1300.6 is implemented by the following regulations of the service: For the Army: Army Regulation (AR) 635-20 (July 31, 1970), as revised, October 1971; for the Navy: Bureau of Personnel Notice (BuPersNote) 1900.6 (Oct. 20, 1971); for the Air Force: Air Force Regulation (AFR) 35-24 (Oct. 18, 1971); for the Marine Corps: Marine Corps Order (MCO) 1306.16o (Nov. 19, 1971).

- The litigation concerning in-service conscientious objectors who have received educational benefits takes place only in the federal courts and is governed by federal law. This is because the "scope, nature, legal incidents and consequences of the relation between persons in service and the Government are fundamentally derived from federal sources." United States v. Standard Oil Co., 332 U.S. 301, 306 (1947).

s See Brown v. McNamara, 387 F.2d 150 (3d Cir. 1967), cert. denied, 390 U.S. 1005 (1968); Hammond v. Lenfest, 398 F.2d 705 (2d Cir. 1968).

- See Welsh v. United States, 398 U.S. 333 (1970); United States v. Seeger, 380 U.S. 163 (1965).

"In this comment, "in-service" will be used to designate any individual who has made an agreement to serve a tour of duty in exchange for educational benefits. Thus, the term will refer to individuals who are still attending educational institutions as well as those on active duty. 
duty. ${ }^{8}$ Since no other recourse is provided by statute or regulation, the services are left to whatever judicial remedies they might have under their contracts with the defaulting individuals.

With respect to the judicial remedies available to the United States as a plaintiff in civil litigation, it is a settled rule that the courts are open to the United States as they are to private citizens. ${ }^{9}$ While as a sovereign the United States may not be sued without its consent, ${ }^{10}$ it may, like a private litigant, maintain any appropriate action at law or in equity to enforce its contracts. ${ }^{11}$ Furthermore, the construction of contracts between the Government and individuals is determined by reference to the general rules governing the interpretation of contracts between private individuals. The fact that the United States is a party to a contract is not material with respect to the obligations of the parties under the terms of the contract.12

The general rule that the United States might seek the same legal and equitable remedies available to private parties in a contractual relationship has been called into question by $\mathrm{McCullough}$ $v$. Seamans. ${ }^{13}$ In this case the Government sought restitution for educational benefits conferred on members of the armed forces who requested discharge as conscientious objectors. In spite of what was apparently a good cause of action at common law, the district court treated the case as nonjusticiable and deferred to the Congress for the creation of any liability. In reaching this conclusion the court held that the case raised a "fiscal question" inappropriate for judicial determination.

This comment argues that the $M c$ Cullough case does present a justiciable issue and that the Government should be allowed to recover the costs of educating a nonperforming service member on a theory of unjust enrichment. Part I of the comment examines the general judicial response to the issue of in-service conscientious objectors who have received educational benefits and identifies the

\footnotetext{
" Other unanticipated difficulties are described in Cusick, In-Service Conscientious Objection, 25 JAG. J. 35 (1970).

- See, e.g., United States v. Summerlin, 310 U.S. 414 (1940); Curtner v. United States, 149 U.S. 662 (1893).

10 On sovereign immunity generally, see K. Davis, Administrative LaW Treatise $§ \S$ 25.01-25.17 (1958).

"See, e.g., United States v. Verdier, 164 U.S. 213 (1896); United States v. Pinson, 102 U.S. $548(1880)$.

${ }^{12}$ See, e.g., Perry v. United States, 294 U.S. 330 (1935); Lynch v. United States, 292 U.S. 571 (1934). The Government is treated differently in that it is not barred by laches, statutes of limitation, or estoppel. On this point, see Chesapeake \& Delaware Canal Co. v. United States, 250 U.S. 123 (1919); United States v. Verdier, 164 U.S. 213 (1896).

13348 F. Supp. 511 (E.D. Cal. 1972).
} 
weaknesses and problems raised by the reasoning and result in the McCullough decision. Part II discusses the precedents on which $M c C u l l o u g h$ rests and shows why reliance on these precedents is misplaced. This section then analyzes the $M c C u l l o u g h$ fact situation within the more relevant framework presented by the Supreme Court in Baker v. Carr in order to demonstrate that the issue raised is appropriate for judicial determination. Part III of the comment explores the nature of the contractual remedy which the Government should be allowed to pursue in suits against in-service objectors.

\section{The Judicial Response to the Issue}

The federal district courts which first dealt with the issue of inservice conscientious objectors owing military duty in exchange for educational benefits had no difficulty in dealing with the problem. ${ }^{14}$ These courts mistakenly believed that all conscientious objectors remained subject to the alternative civilian service program operated by the Selective Service System; the habeas corpus writs in these cases were conditioned on the petitioners' agreement to perform such service. ${ }^{15}$ In 1973 the Eighth Circuit, after analyzing the applicable statutes and regulations, concluded that the district courts had no authority so to condition the habeas corpus writs. ${ }^{16}$ In the same year the Tenth Circuit held that the imposition of any conditions on the conscientious objector discharge is an issue which should be resolved in Congress "and not in the federal courts on a case by case basis." 17 Thus, the use of the alternative service mechanism has been effectively precluded in cases of this type in the absence of explicit Congressional direction. ${ }^{18}$

Courts have also attempted to attach other conditions to the writ of habeas corpus to ensure that the Government is not prejudiced by the default of the conscientious objector. In Miller v.

1" Strait v. Laird, 464 F.2d 205 (9th Cir. 1972); Packard v. Rollins, 422 F.2d 525 (8th Cir. 1970); United States -ex rel Brooks v. Clifford, 409 F.2d 700 (4th Cir. 1969); Osborne v. Seamans, 318 F. Supp. 41 (D. Md. 1970); Moore v. Connell, 318 F. Supp. 884 (D. Md. 1970).

${ }_{15}$ The district courts conditioned the writs sua sponte; the Government did not seek such a remedy.

${ }^{16}$ Mosely v. Commanding Officer, 480 F.2d 1107 (8th Cir. 1973).

17 Smith v. Laird, 486 F.2d 307, 314 (1973).

18 This comment takes the position that the imposition of the alternative service remedy is a matter which should be left to the Congress to decide. This position is taken because such a remedy is not a regular contractual remedy of the type which would be available if the litigation were between private parties. The comment argues that the Government should be allowed to pursue common law contractual remedies, not that it should have remedies based on the peculiarities of the Government-citizen relationship. 
Chafee, ${ }^{19}$ a member of the Navy had applied for conscientious objector status after four years of sponsored undergraduate education. The district court conditioned the writ of habeas corpus on the petitioner's agreement to repay the Government the entire cost of his education. The Ninth Circuit invalidated this condition as "an unauthorized burden on Miller's exercise of his right to seek conscientious objector status, impairing his First Amendment rights." ${ }^{20}$ This appeal to the Constitution as the ground for voiding the conditional writ has, as yet, attracted no adherents, nor is it likely to do so in the future. The Ninth Circuit panel failed to recognize that the federal courts have consistently held that the Constitution does not require exemption from military duty for conscientious objectors. ${ }^{21}$

The district court in the McCullough case also refused to impose liability for educational costs on in-service conscientious objectors, but rested its decision on more ambitious grounds which potentially have undesirable consequences for the Government as a plaintiff in civil litigation. In this case two graduates of the Air Force Academy, still owing five years of active duty each in exchange for their Academy educations, had filed for discharge as conscientious objectors while attending law school. The Air Force rejected their applications and the applicants petitioned the court for writs of habeas corpus. The writs were issued and the Air Force counterclaimed, choosing to rely on the common law theory that the applicants had rescinded their service contracts and should make restitution to restore the status quo ante. The Air Force asked that each applicant be required to pay $\$ 53,575$ to the Government for the cost of educational benefits received.

In refusing to reach the merits of the Government's counterclaim, Chief Judge MacBride asserted that the issue was "essentially a question of fiscal policy far too involved for simple contract principles to settle." ${ }^{22}$ The court viewed the government counterclaim as an attempt to create a new type of liability where none had existed before. ${ }^{23}$ The court was also concerned about its inability to balance the policy considerations involved in this issue;

13 462 F.2d 335 (9th Cir. 1972).

20 Id. at 338 .

${ }^{21}$ See United States v. Macintosh, 283 U.S. 605 (1931); United States v. Fleming, 344 F.2d 912 (10th Cir. 1965); Bouziden v. United States, 251 F.2d 728 (10th Cir.), cert. denied, 356 U.S. 927 (1958). Although commentators have recently criticized these decisions the Miller opinion made no use of their objections. See, e.g., Lurie, Conscientious Objection: The Constitutional Questions, 73 W. VA. L. Rev. 138 (1971); Comment, 56 CAL. L. Rev. 379 (1968).

22348 F. Supp. 511, 513 (1972).

2 Id. 
such a balancing process was seen as a legislative, not a judicial, function. ${ }^{24}$ The court found support in two Supreme Court decisions for its reliance on the fiscal question concept of deference to the Congress, ${ }^{25}$ and, in concluding that the issue was inappropriate for judicial determination, implicitly relied primarily on the separation of powers doctrine. ${ }^{26}$

There are two major defects in the reasoning employed by the court in McCullough. The first defect has to do with the quality of the analysis presented by the court; the court's analysis is not sufficiently critical or discriminating to justify the result which is reached. ${ }^{27}$ Whenever a court reaches a decision which is contrary to established precedent, as is the result in McCullough, that court should assume the obligation to explicate fully its rationale. The court in $\mathrm{McC}$ Cullough, however, fails to do this; instead, the court relies uncritically on the conclusory term "fiscal" to justify its decision that the issue is nonjusticiable. The creation of an ill-defined class of fiscal questions which demand deference to the Congress would place an unwelcome gloss on the common law; if such a category exists, clearer guidelines are needed than those provided by Judge MacBride.

As long as legislatures are not omniscient, there will always be gaps in any statutory scheme; common law courts have traditionally filled these gaps when, as in McCullough, the common law claim is well-supported by legal theory and custom. If a common law court refuses to fill in the gaps left by a statutory scheme, then it is issuing an open invitation to the avoidance of obligations. This ill-effect should not require the courts to decide all meritorious common law claims which do not rest on explicit statutory authority; it does mean, however, that the decision not to decide must be thorough, particularized, and sensitive to the consequences of the result. The court's failure to provide such an analysis in $\mathrm{McC}$ Cullough detracts from the force and credibility of the decision.

24 The policy considerations supporting the various positions of this issue are enumerated, but not analyzed, by the court at 348 F. Supp. 511, 513 (1972). There is no effort to probe the considerations to determine the difficulty of each factor or to determine which considerations demand the closest legislative attention. The court is content with a mere listing of factors from which it concludes that the issue is nonjusticiable.

${ }^{25}$ The decisions are United States v. Standard Oil Co., 332 U.S. 301 (1947), and United States v. Gilman, 347 U.S. 507 (1954). For a fuller discussion of these cases, see text and notes at notes $32-40$ infra.

${ }^{26}$ While the court does not use the term "separation of powers," this is clearly what is meant by the repeated references to the "political processes of Congress" and the superior competence of the legislature to weigh vexing questions of public policy.

${ }^{27}$ See text and note at note 13 supra. 
The second defect in the $\mathrm{McC}$ Cullough reasoning concerns the analytical framework employed by the court. Not only did the court fail to justify its use of the fiscal question concept, but it appears that the court ignored a well-developed doctrine expressly intended for use in cases like $\mathrm{McCullough}$. This doctrine is the political question doctrine as expounded in the leading case of Baker $v$. Carr. ${ }^{28}$

In Baker v. Carr the Supreme Court stated that "it is the relationship between the judiciary and the coordinate branches of the Federal Government . . . which gives rise to the 'political question. " "' ${ }_{29}^{9}$ It is this same concern for the separation of powers that led the court in $\mathrm{McC}$ Cullough to its decision; however, instead of relying on the more recent and relevant Baker decision, Judge MacBride sought support in Supreme Court decisions announced in 1947 and $1954 .^{30}$ Baker $v$. Carr provides an explicit analytical framework for deciding the question of nonjusticiability in the context of the separation of powers doctrine. Instead of using this framework, Judge MacBride resorted to the type of "semantic cataloguing" which was disapproved in Baker $v$. Carr. ${ }^{31}$ The following section of this comment will seek to remedy the McCullough court's deficiencies in reasoning by analyzing the facts and precedents relied upon in light of the analytical framework provided in Baker v. Carr.

\section{McCullough and Nonjusticiability}

A. The Precedents Relied Upon

The rule of restraint announced in McCullough purported to find support in two Supreme Court decisions. The earlier of these-United States $v$. Standard Oil Co. of California ${ }^{32}$-involved a claim by the Government for loss of services and medical expenses arising out of a soldier's injuries caused by the negligence of defendant's employee. Having asserted its authority to make a rule, the Court declined to do so, deferring instead to the Congress to create liability. The Court gave a number of reasons for this decision: that the Government sought to create a new type of liability unknown to the common law; ${ }^{33}$ that the question raises broad issues of fiscal policy beyond the powers of tort law to accommodate $;^{34}$ that since

28 369 U.S. 186 (1962).

369 U.S. 186, 210 (1962).

30 See cases cited at note 25 supra.

it 369 U.S. 186, 217 (1962).

32332 U.S. 301 (1947).

${ }^{3}$ Id. at 305 n.5, 314 .

3 Id. at 314. 
Congress must have been aware of tortious interference with government employees, its failure to act by legislation shows its acquiescence in the lack of a remedy; ${ }^{35}$ and that the Government, unlike a private party, can provide its own recourse by statute.$^{36}$ Each of the reasons advanced by the Court is supported by thorough research and an adequate examination of the consequences of the analysis put forth.

The other case cited in McCullough is United States $v$. Gilman..$^{37}$ Like Standard Oil, it involved a government suit in tort. The United States had been held liable under the Federal Tort Claims Act for the negligence of its employee and sought to recover from the employee under the rule that one who has been held liable under respondeat superior may sue for reimbursement from the negligent servant. Justice Douglas, writing for the majority, emphasized that the matter was in court only because the Government had consented to be sued initially under the Federal Tort Claims Act, which has no provision for the liability of government employees. ${ }^{38}$ The majority also claimed, in a footnote, to find positive evidence in the legislative history of the Tort Claims Act that Congress did not intend to create a cause of action against the Government's employees. ${ }^{39}$ The final reason for dismissal relied upon by the Court in Gilman was borrowed from the Standard Oil decision. The Court found that the suit raised fiscal questions better addressed by the Congress-in particular, whether the good relations of the Government with its employees should outweigh the Treasury's need to be compensated for its loss. ${ }^{40}$

The McCullough decision can be distinguished on several grounds from the precedents on which it relies. ${ }^{4 I}$ For purposes of this analysis, however, only one of these distinguishing characteristics is significant. The McCullough decision, unlike Standard Oil and

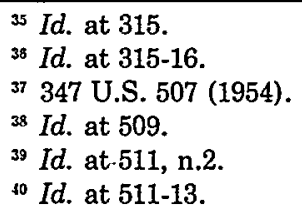

"Unlike the Standard Oil majority, the McCullough court did not purport to find the common law doctrine presented unpersuasive; nor could it have assumed that Congress had known of the problem for some time and had intentionally declined to act. In McCullough the problem involved probably was not of the magnitude which would have attracted the attention of Congress independently and probably was not dealt with in the Selective Service Act because of the insignificance of in-service conscientious objection prior to the Vietnam era. Moreover, unlike Gilman, the McCullough court did not rely on legislative history or on the view that the case was really governed by a statute in which the relief demanded had no place. 
Gilman, relies entirely on the fiscal question concept without careful supporting analysis of the type found in the two Supreme Court decisions. Thus, the strength of the $\mathrm{McCullough}$ decision must be measured by the strength and appropriateness of the analytical concept that Judge MacBride employed. Although it cannot be doubted that it was proper for the Supreme Court in Standard Oil and Gilman to employ the fiscal question concept as a single strand in the development of each of the decisions, it is more difficult to justify the $M c C$ Cullough court's uncritical reliance on the concept. At the time Standard Oil and Gilman were decided there had been no exhaustive study or definitive pronouncement by the Supreme Court on the issue of judicial restraint based on the separation of powers. The decision in Baker $v$. Carr has, however, provided such an analysis, an analytic construct which the $\mathrm{McCullough}$ court chose to ignore. It is to Baker $v$. Carr that this comment now turns in order to examine more closely and systematically the fiscal question doctrine and to provide a more satisfactory examination of the justiciability of cases similar to McCullough.

\section{B. The Baker v. Carr Framework}

In Baker $v$. Carr the Supreme Court was faced with the claim that the existing apportionment of the Tennessee state legislature produced inequality of representation and thus was a violation of the equal protection clause of the fourteenth amendment. The district court had dismissed the complaint for lack of jurisdiction of the subject matter and for want of a justiciable issue. The Court reversed, holding that a claim that the apportionment of a state legislature denied equal protection presented a justiciable issue. The Court consciously went further in its analysis than was necessary to resolve the case in order to present a definitive pronouncement on the political question doctrine. ${ }^{42}$ The Court repeatedly made the point that independent inquiry is necessary in each case to establish the existence of a political question..$^{43}$ In addition to this admonition, the Court provided a list of six factors ${ }^{44}$ which must be

12369 U.S. 186, 206 (1962).

${ }^{43}$ Id. at $210-11,211,217$.

"Only three of the factors will be discussed in the text. The remaining three may be treated more briefly as follows: (1) "[A] lack of judicially discoverable and manageable standards for resolving" the issue, 369 U.S. at 217 . In deciding the in-service conscientious objector cases, separate standards are needed for determining (a) liability and (b) damages. The standards developed in common law contract and restitution cases provide the liability standards. For the development of standards with respect to damages in these cases, see text and notes at notes 72-74 infra. (2) "[A]n unusual need for unquestioning adherence to a 
considered in determining if an issue is nonjusticiable by virtue of the political question doctrine. It is clear that "unless one of these [factors] is inextricable from the case at bar, there should be no dismissal"45 on the ground of the political question doctrine.

The first factor listed by the Court in Baker is a "textually demonstrable constitutional commitment of the issue to a coordinate political department." 46 The fiscal power of the Congress, as textually granted by the Constitution, includes the power to levy taxes and to appropriate funds as needed in support of the national government's functions. ${ }^{47}$ It would be novel to suggest that the prerogatives associated with the taxation and appropriation powers extend to every monetary claim made on behalf of the Treasury. ${ }^{48}$ Such a rule has the potential to make every suit by the United States on a government contract, for example, a legislative question. While it is prudent for the courts to decline to create wholly new classes of public obligations which the Treasury is unprepared to meet, ${ }^{49}$ there is no reason emanating from the text of the Constitution that requires a special statutory mandate to enforce an obligation owed to the Government if the Government's claim is wellsupported at common law.

Additional considerations support this conclusion. Even though the "textually demonstrable commitment" factor probably could not have been established in this case under the standard as expressed in Baker, the Supreme Court has further narrowed the con-

political decision already made." 369 U.S. at 217 . This factor is not applicable since no previous political decisions have been made on the subject by Congress. (3) The "potentiality of embarassment from multifarious pronouncements by various departments on one question." 369 U.S. at 217. Embarassment for the executive branch is likely to occur if the courts do not decide the issue, for it is the executive which has initially chosen to bring the suit. Furthermore, since Congress is not likely to pass legislation on this specific issue (see note 41 supra), it is unlikely that such embarassment will result.

ts 369 U.S. 186, 217 (1962).

4 Id.

4 U.S. ConST., art. 1, §§ 8-9.

48 It is necessary to keep in mind the distinction between the situation where the Government is the plaintiff in a civil suit and where the Government is the defendant. In the latter case, suit cannot be brought against the Government in the absence of an explicit congressional waiver of sovereign immunity. The implication of the $M c C$ Cullough decision is that explicit legislative approval is needed for the Government to act as a plaintiff in support of its interests and rights. The need for symmetrical treatment of the Government as a defendant and as a plaintiff with respect to congressional approval has not heretofore been established in the American legal system. Indeed, the doctrine of sovereign immunity and the established rule concerning the Government as a plaintiff (see notes 9-12 supra) have always co-existed.

49 This would have been the case if, for example, the courts rather than the Congress had waived sovereign immunity to suit in tort. 
tours of this factor in Powell v. McCormack. ${ }^{50}$ Under the standard announced in that case, something more than a mere textual commitment must be found; ${ }^{51}$ in the case of the taxation and appropriation powers, there is no textual reference at all to suits by the Government on monetary matters or to fiscal powers in general. The decision as to whether a suit on a government contract should be allowed has not been committed specifically and textually to the Congress by the Constitution.

Another significant factor presented in Baker is the "impossibility of a court's undertaking independent resolution without expressing lack of the respect due coordinate branches of the government." 52 In the case of in-service conscientious objectors, it is the executive branch which is bringing the suit and, therefore, judicial resolution would not be disrespectful to this branch of the national government. In addition, it is likely that cases like $M c C u l l o u g h$ will not be brought frequently and thus the total amount of money involved will not be significant in relation to the total national budget. Because of the minor impact of these cases, this issue is unlikely to be even addressed by the Congress; ${ }^{53}$ disrespect would not be shown the Congress by deciding such a case.

The likelihood of congressional action on a given issue is a relevant factor in determining the chances for conflict with a coordinate branch; the $\mathrm{McCullough}$ court failed to analyze and appreciate this element of the situation. While it appears that the likelihood of confrontation between the judiciary and the legislature is slight in this situation, there is a readily available solution if a disagreement should develop..$^{54}$ The Congress can override the decision of the court simply by passing a statute. ${ }^{55}$ Thus, it is exceedingly unlikely

50395 U.S. 486 (1969).

s1 This extra element consists of positive evidence that the Framers of the Constitution intended the specific action at issue to be committed to a particular branch of the national government. It is not sufficient that the authority for the contested action can be inferred from more specific grants of power.

s2 369 U.S. 186, 217 (1962).

53 See note 41 supra, concerning the most likely reason for this gap in this statutory scheme.

st The legal system has shown that it can deal with confrontations of a much greater magnitude than is represented by the in-service conscientious objector issue. See, e.g., Youngstown Sheet \& Tube Co. v. Sawyer, 343 U.S. 579 (1952), and Brown v. Board of Education, 347 U.S. 483 (1954). Indeed, the checks and balances doctrine which is so basic to the American constitutional system actually requires a certain amount of confrontation among the branches of the national government.

${ }_{55}$ This is precisely what the Congress did in response to United States v. Standard Oil Co., 332 U.S. 301 (1947). See 42 U.S.C. $\$ \S 2651-53$ (1970). There have been no evident repercussions of the type feared in Baker $v$. Carr because of this action. 
that disrespect of a magnitude uncommon to our legal system will develop if the courts hear the Government's claim against in-service conscientious objectors who have received educational benefits.

The final factor presented in Baker $v$. Carr is the "impossibility of deciding without an initial policy determination of a kind clearly for nonjudicial discretion." This factor is most relevant to the inservice objector issue since it is the reason underlying the McCullough decision. This factor, however, should not be a bar to the justiciability of cases like $M c$ Cullough. Policy questions such as whether the loss to taxpayers from forgiving the obligations owed by in-service objectors should outweigh the deference to be paid to conscience are, of course, matters which might interest Congress. And a weighing of such public policy considerations might, once undertaken, produce a result different from that of contract law. But this reasoning proves too much: the possibility of displacement by statute on political grounds is common to all the remaining preserves of common law.

While judge-made and statutory law supplement one another, they are the result of quite different processes, responding to different pressures and seeking-whatever the extent of overlapdifferent ends. Statutory law, made in pursuit of political, economic, or social ends, may effectively abolish common law rights and liabilities. No-fault insurance statutes are a stark example of this type of displacement. Abolition occurs, however, not because common law is inadequate on its own terms to decide cases of a given kind, but because a political decision is made that particular economic and social needs must prevail over judge-made rights and obligations. The $\mathrm{McC}$ Cullough theory would apparently enable courts to anticipate this process and to abrogate their jurisdiction accordingly. ${ }^{56}$

The case of no-fault automobile compensation plans serves as an example of the $\mathrm{McCullough}$ theory's potential. The judiciary has surely been aware for some time of the rising social costs of accidents. It would have taken little imagination to suppose that legislatures, confronted with the policy questions concerning the distribution of these costs, might be interested in finding less costly ways of dealing with the problem. Yet few would think it helpful if the courts, before the legislatures take any action, were to declare

${ }^{58}$ This comment, on the other hand, argues that the process of court decision followed by legislative action, if thought necessary, should not be abrogated in the absence of more compelling reasons and analysis than are presented by the McCullough court. 
damage suits arising from automobile accidents nonjusticiable because of the policy questions they raise.

The $M c$ Cullough opinion suggests a false dichotomy with respect to the ability of courts to weigh policy considerations. The decision suggests that courts must either decide cases without reference to broader policy questions, or decline jurisdiction and hope that the legislature will make law that accommodates the broader equities. In fact, courts have shown considerable ability to weigh policy considerations and to produce decisions and rules which take them into account. The products liability decisions of the California Supreme Court ${ }^{57}$ under Chief Justice Traynor rely on policy considerations which could have been dismissed as too complex for judicial treatment. Yet these decisions are no more legislative for taking into account policy considerations than no-fault statutes are judicial because they overturn much of what judges have built.

In $\mathrm{McCullough}$ the court was presented a concrete case between adverse parties who would be certain to represent effectively their points of view and who would be individually affected by the outcome of the suit. The court did not claim a judicial decision would work injustice to the litigants. Rather, the court suggested that, as prospective rules, the liability demanded might strike the Congress as fiscally defective. If there is such a defect it is only for the Congress-not the court-to determine. The first task of a court remains to declare the rights of the parties who stand before it. The Baker formulation would have the courts abrogate this important function only when the policy concerns are "clearly for nonjudicial discretion;" no policy concerns present in the McCullough case are sufficient to justify the extreme step of declaring an issue nonjusticiable. To be sure, policy issues are present in the case, ${ }^{58}$ but the legal grounds on which to decide the issues of liability and damages are sufficiently clear so that they should not be submerged by these policy concerns.

\section{The Contractual Liability of Conscientious Objectors Who Have Received Educational Benefts}

If the foregoing conclusion that the Government should have the right to sue at common law in cases like McCullough is accepted, then the question of the liability of conscientious objectors

57 See Greenman v. Yuba Power Products, 59 Cal. 2d 57, 377 P.2d 897, 27 Cal. Rptr. 697 (1962); Escola v. Coca-Cola Bottling Co., 24 Cal. 453, 150 P.2d 436 (1944).

${ }^{5 \times}$ See note 24 supra. 
owing terms of service promised in exchange for educational benefits would be one for ordinary principles of contract law to resolve. ${ }^{59}$ The facts of $\mathrm{McCullough}$ and similar cases are sufficient to prove liability and damages for breach of the agreement to serve.

The educational programs in question all involve reciprocal promises by the service member and the Government. The pledge by the military to finance particular education or training is contractual consideration for the serviceman's promise to make his skills available to the military for a fixed period of time. The duty to serve is absolute upon completion of the government-financed education.

Those who complete government-financed education, and are subsequently discharged as conscientious objectors, have failed to perform as promised. This failure to perform is not privileged; the Directive authorizing conscientious objector discharges purports to affect no legal relationship beyond the duty of continued military service. ${ }^{60}$ The Directive does not state or imply that those who qualify for its protection are thereby released from ordinary contractual obligations.

It has been suggested, however, that the duty of performance on the part of conscientious objectors may be treated as discharged by supervening impossibility of performance. ${ }^{61}$ The rationale is that development of conscientious objection is involuntary and resembles other unforeseen events which intervene between the making of a promise and the time appointed for its performance. Discharge for impossibility, if found, might give rise to a claim by the Government for restitution of the value of any benefits received by the conscientious objector, but would avoid the claim of breach of contract. ${ }^{62}$

The difficulty with this view is that it makes involuntariness the sine qua non of impossibility. In fact, the operative distinction is not between voluntary and involuntary, but between subjective and objective impossibility. ${ }^{63}$ If a supervening event makes it impos-

${ }^{59}$ This would be, in other words, a return to the established rules concerning the status of the Government as a plaintiff in civil litigation whereby the Government is entitled to seek normal judicial remedies for the violation of its common law rights. See text and notes at notes 9-12 supra.

${ }^{6}$ DoD Directive 1300.6 (1962).

ot Such a suggestion is made in Albrecht, Recovery of Government-Funded Education Expenses, 26 JAG. J. 157, 160 (1972). (1932).

${ }^{22}$ See Restatement of Restitution, § 108(c) (1937); Restatement of Contracts § 468(2)

63 Restatement of Contracts $\S 455$, comment $a$ : "It is the difference between "the thing 
sible for anyone to perform the obligation-as when the unique subject matter of a bargain is destroyed-then the duty may be discharged because of objective impossibility. Events such as insolvency, ${ }^{64}$ on the other hand, which may be equally unwilled and unforeseen, prevent only the particular promisor's performance. They are termed subjective and do not discharge the promisor's obligation. The quickening of conscience which leads a service member to seek conscientious objector status is a more difficult case, but it appears to be similar to the case of bankruptcy for purposes of classifying the event as subjective or objective. The unique subject of the bargain - the conscientious objector's physical ability to serve-has not been destroyed; only his willingness to serve has become impossible.

A more interesting approach to the question of whether the duty of the conscientious objector has been discharged is that of assumption of risk. ${ }^{65}$ The relevant inquiry with respect to this approach concerns the question of whether the Government, either expressly or by implication, has shown its intention to absorb losses from this source. The matter is often phrased in the following manner: if the Government had bargained with the defendant on this issue, would the Government have agreed to bear this loss?66

The best, albeit not conclusive, evidence available on this point is the Government's behavior when it has bargained over similar risks. The petitioners in the conscientious objector cases share two relevant categorical traits: they are conscientious objectors, and they are recipients of educational benefits which carry a service commitment. The Government has addressed the issue, as to each category of persons, of the obligations which accompany the privilege of being excused from performance of the military obligation which has been undertaken.

Conscientious objectors receive statutory attention in the Selective Service Act. Those who are excused from military duty on the basis of conscientious objection are required to perform alternative civilian service of value to the nation for a period equal in length

cannot be done' and 'I cannot do it' ". The promisor's obligation is discharged only in the former case.

" See, e.g., Christy v. Pilkinton, 244 Ark. 407, 273 S.W. 2d 533 (1954); Title and Trust Co. v. Durkheimer Inv. Co., 155 Ore. 427, 451-52, 63 P.2d 909, 919 (1936).

is See generally F. Kessler \& G. Gilmore, Contracts: Cases and Materials 742-82 (2d Ed. 1969).

“ See, e.g., National Presto Industries Inc. v. United States, 338 F.2d 99 (Ct. Cl. 1964), cert. denied, 380 U.S. 962 (1965). 
to that of the general military obligation. ${ }^{67}$ The legislative history of this remedy shows an intention to prevent abuse of the exemption by ensuring that it confers no absolute privilege of escape from the universal duty to serve. ${ }^{68}$ The aim of the alternative service remedy is deterrence; punitive purposes are expressly rejected. ${ }^{69}$

Among the various military educational programs, the service academies are governed by the most elaborate statutory scheme. The obligation imposed on a cadet who refuses his commission, and thereby avoids his obligation to perform five years of commissioned service, is a maximum four-year tour of enlisted duty. ${ }^{70} \mathrm{Here}$, as in the statute governing pre-induction conscientious objectors, the remedy provided ensures that the service obligation is not avoided altogether and that some work of national importance is done by the non-performing cadet. No punitive measures are authorized; the cadet does not have to repay the cost of his education.

If the remedies provided by statute are a reliable guide, the Government would not have bargained away all right of recovery for breach of contract if the question of conscientious objection had been raised during negotiations with the recipients of educational benefits. Although there has never been an explicit provision authorizing monetary recovery by the Government in the case of conscientious objectors or recipients of educational benefits, this omission can be explained by the fact that the superior remedies of (1970).

${ }^{67}$ Selective Service Act of 1948, 62 Stat. 612 (1948), as amended 50 U.S.C. $\$ 456(j)$

os "Alternative service" began informally during World War I when the War Department furloughed objectors who refused to perform even noncombatant duties with the combat forces to Red Cross and agricultural work vital to the nation. The Third Assistant Secretary of War summarized the policy this way in 1918:

In short, every effort is being made to respect the sincere scruples of a small minority of our people, at the same time that their power to contribute to the nation's efficiency is turned to good account; . . . . a method which conserves the manpower of the Nation, and accords to furloughed objectors a lot that is endurable and serviceable, but in no sense pampered, will, it is believed, commend itself to the common sense and practicality of the American people."

Selective Service System Special Monograph 11, Conscientious Objection at 63 [hereinafter cited as MONOGRAPH].

It was this program which, largely at the urging of religious groups who gave extensive congressional testimony on the question, was used as the model for the alternative service provision of the Selective Service Act of 1940. The provision was carried over into the 1948 act without debate. See Id. at 69 .

${ }^{69}$ While it is true that most alternative service during World War II was performed in civilian-run camps, these were an outgrowth of the Civilian Conservation Corps camps already in operation. The point of using camps was no more punitive than under the CCC; it was an administratively convenient way of ensuring that work of acknowledged public importance would be done by the objectors. See MoNograph at 160-61.

${ }^{70} 10$ U.S.C. $\S 9348$ (1970). 
induction and alternative service have been available. In cases like McCullough, however, the induction remedy of the academy statutes cannot be imposed. In addition, alternative service, while useful to the nation, does not meet any specific purpose for which the military has bargained. Thus, it can be argued with some confidence that the military would have bargained for a contractual liability provision which would benefit the services more directly-in this case, a recovery for funds expended to educate the nonperforming individual. If the military is able to recover such funds, there is a greater likelihood that the total effective monetary commitment to military-sponsored education for the purpose of producing commissioned officers will not be reduced significantly. ${ }^{11}$

Once the Government has proved contractual liability, it must choose between the two remedies available in this situation. The Government might treat its contract with the conscientious objectors as rescinded and seek restitution, or it might enforce the contract and demand to be compensated for the loss of the benefit of its bargain. The choice will make little practical difference where, as in Smith v. Laird ${ }^{72}$ the Government merely paid the defendant's tuition at a civilian university. Contract damages would be subject to the duty to mitigate and would likely amount to tuition plus the costs incurred by the service in securing another trainee to replace the defendant. ${ }^{73}$ Restitution, ${ }^{74}$ on the other hand, would amount to restoration of the tuition amount to the Government.

Providing education at the service academies presents a more difficult problem. Since the Government pays the entire cost of running these institutions, a claim for restitution might seek either of two measures of recovery: the defaulting cadet's share of the cost of running the academy (the Government's reliance interest), or the amount of tuition the cadet would have paid to secure an equivalent education in a civilian university (the amount of the cadet's unjust

"If the government is able to recover the funds spent on educating nonperforming individuals through judicial action, there is greater likelihood that this money will be used for the same purpose in the future; that is, to replenish the funds previously appropriated but spent on the educations of persons who did not become commissioned officers as intended. If, however, these funds are not recovered, it is not clear that the Congress will appropriate sufficient funds to affect the reduction in the number of commissioned officers caused by the in-service conscientious objector provision.

72486 F.2d 307 (10th Cir. 1973).

is See 5 A. Corbin, Contracts $\$ 1096 ; 5$ S. Williston, Treatise on the Law of Contracts $\S$ 1362A (Rev. ed. 1937).

"For an explanation of the concepts of restitution, reliance interest, and unjust enrichment, see Fuller \& Purdue, The Reliance Interest in Contract Damages, 46 Yale L.J. 56 (1936). 
enrichment). In McCullough, the Government sought the former, larger measure of recovery.

There are at least two reasons for preferring that the Government be permitted to recover no more than the amount of a cadet's true unjust enrichment from attending a service academy. First, and less important, this alternative presents fewer problems of measurement. Merely dividing the cost of running an academy by the number of cadets, and treating the result as the defendant's share, begs the question of causation. Many costs are more or less fixed, so that if the defaulting cadet had not attended and no one had been there in his place, the cost of running the institution would not have been reduced in proportion.

Given the flaws in this method of measurement, the preferable measure of unjust enrichment would appear to be the amount of tuition which the nonperforming cadet would have paid at a civilian university. This method presents but one major problem, that of determining whether the tuition at a state (public) or private university is to be used in determining the amount owed by the cadet. Since an inquiry into the cadet's pre-college ${ }^{75}$ plans would thrust the court into the unwieldy stance of determining past and perhaps indeterminable motives; this technique should not be employed. Rather, a sounder approach would be to assess the nonperforming cadet an amount which corresponds to the average of the tuition cost at public and private universities for a given year. ${ }^{76}$ This approach avoids inquiry into motives, provides the court with definite cost figures with which to work, and arrives at a fair cost for determining unjust enrichment.

The stronger reason for not imposing the more onerous reliance measure of restitution is its punitive effect. Granting remedies such as the $\$ 53,575$ demanded in $M c$ Cullough would tend to discourage the legitimate exercise of the conscientious objector privilege. The recourse provided for the Government under the Selective Service System evidences a congressional purpose to deter abuse of the privilege while scrupulously avoiding punitive measures against those who invoke it. ${ }^{77} \mathrm{~A}$ similar, nonpunitive intent appears in the

${ }^{75}$ Pre-college refers to any period before the specific decision deciding which educational program is to be pursued, not just to the decision with respect to undergraduate education.

${ }^{76}$ Various professional organizations, such as the American Association of Colleges and Universities and the American Association of University Professors, provide annual figures which show the median tuition cost of public and private education in various regions of the United States. These sources can provide the courts with realistic and definite cost figures as to the cost of education.

$\pi$ See text and notes at note 69 supra. 
alternative military service required of academy graduates who refuse to be commissioned. ${ }^{78}$ Given this congressional attitude, the courts should not impose crushing financial burdens on those who exercise a statutory privilege which the Government has pledged to respect.

\section{Conclusion}

This comment has argued that the issue raised in $\mathrm{McCullough}$ does not involve a political question and that, when suing an inservice conscientious objector, the Government should be allowed to recover the amount of the nonperforming individual's unjust enrichment. This return to the established rule that the Government should have access to the courts to protect its interests by wellpleaded common law suits would not require courts to ignore the Government's peculiar position as a party to a suit. Here, as elsewhere, where the Government has discretion to act or not, it should be held to its constitutional responsibilities. If the Government enforces its common law rights in a discriminatory or standardless manner, it can be denied relief. But these matters can be raised by defendants as defenses within the structure of a lawsuit; neither they nor the policy issues imbedded in these actions make these suits by the Government nonjusticiable.

Charles H. Kennedy

${ }^{7 \pi}$ See text and notes at note 70 supra. 